організацій N 291 від 30.11.99 [із змінами та доповненнями] [Електронний pecypc]. - Режим доступу: http://zakon.rada.gov.ua/ cgi-bin/ laws/ main. z0893-99.

8. Національне положення (стандарт) бухгалтерського обліку 1 «Загальні вимоги до фінансової звітності», затверджене наказом Міністерства фінансів України №73 від 07.02.2013.[ із змінами та доповненнями ] [Електронний pecypc]. - Режим доступу: http://zakon2.rada.gov.ua/ laws/show/z0336-13

\title{
ЦИТ: ua117-083
}

DOI: $10.21893 / 2415-7538.2016-05-1-083$

УДК 336.67

Невгад Ю.О.

ШЛЯХИ ВДОСКОНАЛЕННЯ ОБЛІКУ ФІНАНСОВИХ РЕЗУЛЬТАТІВ ДІЯЛЬНОСТІ ПІДПРИЕМСТВА

Київський національний університет імені Тараса Шевченка

Київ, Васильківська 90А, 03022

Nevhad Y.O.

\section{WAYS TO IMPROVE ACCOUNTING FOR FINANCIAL PERFORMANCE OF THE COMPANY}

Taras Shevchenko National University of Kyiv

Kyiv, Vasylkivska 90A, 03022

Анотація. У статті розглянуто існуючі проблеми формування та обліку фінансових результатів діяльності підприємств. Розкрито сутність поняття «фінансові результати діяльності» як економічної категорії. Окреслено вітчизняні підходи та методи аналізу формування фінансових результатів. Надано пропозиції щзодо покращзення та підвищення ефрективності обліку фінансових результатів.

Ключові слова: фінансовий результт, прибток, доходи, витрати.

Abstract. In the article the actual problems of formation and accounting of financial results of enterprises. The essence of "financial activities" as an economic category. Scheduled national approaches and methods of analysis of financial results. Proposals for improving the efficiency of accounting and financial results.

Keywords: financial performance, revenue, income, expenses.

Вступ. У процесі розвитку ринкових відносин усі підприємства України зіткнулися 3 рядом проблем щодо визначення фінансових результатів та відображення їх у обліку. На сучасному етапі велика кількість підприємств $є$ неприбутковими або ж малоприбутковими, а одним 3 найважливіших показників, що характеризує ефективність фінансової діяльності підприємства, $\epsilon$ фінансовий результат: прибуток чи збиток. Фінансовий результат діяльності це найважливіший показник, що цікавить всіх користувачів облікової інформації. Отже, проблема знаходження шляхів підвищення прибутковості підприємств є актуальною в умовах сьогодення і має бути досліджена.

Виклад основного матеріалу. При формуванні фінансового результату використовується один 3 найголовніих бухгалтерських принципів, принцип достовірності, що вимагається при складанні та поданні фінансових звітів, 
міжнародних стандартів фінансової звітності, Закон України «Про бухгалтерський облік та фінансову звітність в Україні», Національні положення (стандарти) бухгалтерського обліку тощо. Передусім необхідне чітке розуміння поняття «фінансовий результат» - це одна з головних передумов формування обліку, контролю, аналізу та можливості здійснення доцільного управлінського впливу на окремі його складові заради підвищення ефективності діяльності підприємств.

Наразі існують проблеми з чіткою класифікацією фінансових результатів. Підходи до класифікації фінансових результатів за різними ознаками містять суперечливі моменти, навіть на законодавчому рівні, так, наприклад, у 2013 році втратив чинність П(С)БО 3 «Звіт про фінансові результати», в якому визначались основні види фінансових результатів, а у НП(С)БО 1 «Загальні вимоги до фінансової звітності» запропоновано інший перелік показників, який досить сильно відрізняється від того, що застосовувався раніше. Так, за НПСБО передбачено оновлений перелік показників, зокрема: прибуток, фінансовий результат від операційної діяльності, фінансовий результат до оподаткування, прибуток від припинення діяльності після оподаткування, чистий фінансовий результат, інший сукупний дохід до оподаткування, інший сукупний дохід після оподаткування і сукупний дохід[3].

Згідно НП(С)БО 1 не передбачається відображення надзвичайних фінансових результатів з Плану рахунків виключено відповідні рахунки, але не запропоновано відповідних прийомів для відображення таких витрат і доходів у разі їх виникнення. На сьогоднішній день нормативно-правові акти, що регламентують порядок визначення результатів діяльності підприємства, взагалі не містять класифікації фінансових результатів, що могла б бути використана для створення ефективних інформаційних облікових моделей.

На сьогоднішній день існує два принципові підходи до розрахунку фінансових результатів підприємства, які мають деякі модифікації у різних країнах світу:

Таблиця 1

\section{Підходи щодо формування фінансових результатів}

\begin{tabular}{|l|l|}
\hline $\begin{array}{l}\text { База } \\
\text { підходу }\end{array}$ & \multicolumn{1}{c|}{ Характеристика } \\
\hline МСФ3 & $\begin{array}{l}\text { Для визначення фінансового результату рекомендують застосовувати метод } \\
\text { «витрати-випуск». В обліковій практиці зарубіжних країн використовують } \\
\text { два варіанти цього методу: } \\
\text { - передбачається визначення фінансового результату звітного періоду як } \\
\text { різниці між доходами від реалізації і витратами періоду; } \\
\text { - фінансовий результат обчислюється як різниця між вартістю чистих активів } \\
\text { на кінець і початок періоду з виключенням внесків капіталу і вилучень. }\end{array}$ \\
\hline НП(С)БО & $\begin{array}{l}\text { Передбачено формування фінансових результатів за двома системами } \\
\text { залежно від побудови фінансового обліку: }\end{array}$ \\
& $\begin{array}{l}\text { - передбачає зіставлення доходів із витратами, та вартістю розподілу } \\
\text { адміністративних витрат, витрат на збут та інших операційних витрат; } \\
\text { - фінансовий результат обчислюється як різниця між доходами підприємства } \\
\text { та витратами, які акумулюють у звіті про фінансові результати згідно з їхніми } \\
\text { характером. }\end{array}$ \\
\hline
\end{tabular}

Складено автором на основі [1]. 
У більшості країн світу чистий прибуток $є$ ключовим показником фінансових результатів підприємства. У вітчизняних нормативних документах концепції розрахунку прибутку зазначено у НП(С)БО 1, П(С)БО 15 «Дохід», П(С)БО 16 «Витрати», П(С)БО 17 «Податок на прибуток», а також у Плані рахунків та Інструкції по його застосуванню, яким передбачено порядок визначення та обліку фінансового результату аналогічно зарубіжній практиці.

Для обліку фінансових результатів досить важливим є раціональний вибір облікової політики: вибір методу амортизації, методу оцінки вибуття запасів, нарахування резерву сумнівних боргів і т.ін. Все це істотно впливає на фінансовий стан, підприємства та у подальшому знаходить своє відображення у фінансовій звітності підприємства.

Згідно 3 діючим Планом рахунків бухгалтерського обліку активів, капіталу, зобов'язань і господарських фінансові результати формуються в розрізі окремих видів діяльності, кожному з яких притаманні певні доходи i витрати. Діючий при цьому принцип нарахування та відповідності доходів і витрат, одночасно з високим ступенем деталізації даних, створює зручну для складання фінансової звітності систему, яка $\epsilon$ максимально наочною для управлінських прийняття рішень.

У нинішніх умовах проблемним залишається питання щодо неузгодженості класифікації видів діяльності та субрахунків обліку доходів, витрат та фінансових результатів, на яких вони формуються.

Недоліком формування фінансового результату в діючому Плані рахунків бухгалтерського обліку Самохін Л.В. вважає те, що в ньому на субрахунках 791 «Результат операційної діяльності» та 792 «Результат фінансових операцій» фактично об'єднані по два види діяльності підприємства, а саме: на субрахунку 791 - основна та інша операційна діяльність, а на субрахунку 792 - фінансова діяльність. Тому до робочого Плану рахунків підприємства необхідно внести доповнення [4]:

- до субрахунку 791 відкрити два рахунки третього порядку: 7911 «Результат від операційної діяльності» та 7912 «Результат від іншої операційної діяльності»;

- до субрахунку 792 відкрити два рахунки третього порядку: 7921 «Результат від інвестиційної діяльності» та 7922 «Результат від фінансової діяльності».

Згідно із НП(С)БО 1 «Загальні вимоги до фінансової звітності» [1] у статті «Інші доходи» показується дохід від реалізації фінансових інвестицій, неопераційних курсових різниць та інші доходи, що виникають, але не пов'язані 3 операційною діяльністю підприємства, тобто на субрахунку 793 «Результат іншої звичайної діяльності» частково відображаються доходи і витрати від інвестиційної діяльності.

Для того, щоб підприємство могло чітко визначати обсяг та ефективність інвестицій, можна розділити інвестиційну діяльність на основну інвестиційну діяльність та іншу інвестиційну діяльність та деталізувати таку інформацію на субрахунках третього порядку 793 рахунка.

Висновки. Таким чином, на підставі проведеного дослідження можна 
зробити такі загальні висновки. 1. Фінансовий результат $є$ досить складною та багатовимірною категорією. Інформація про результати діяльності відображається у фінансових звітах підприємства та є загальнодоступною інформацією для визначення рівня ліквідності, платоспроможності та фінансової стійкості підприємства. 2. 3 метою покращення та підвищення ефективності обліку фінансових результатів доцільним є: - на законодавчому рівні закріпити сутність поняття «фінансові результати», уточнити перелік показників, які їх характеризують; - розширити перелік класифікаційних ознак; - запровадити єдині класифікаційні ознаки і розмежовування їх за видами діяльності з використанням рахунків третього порядку; - впровадити регістри аналітичного обліку фінансових результатів для узагальнення обліко- вої інформації з метою задоволення інформаційних потреб різних користувачів.

\title{
Література
}

1. Н(С)БО № 1 «Загальні вимоги до фінансо- вої звітності», затв. Наказом МФУ від 07.02.2013 р. № 73: [Електронний ресурс]. - Режим доступу: http://zakon4.rada.gov.ua/laws.

2.Г.П.Голубнича, Економічний аналіз: навчальний посібник /Г.П.Голубнича, Л.І. Панасенко. -К.: Вид.-полігр. центр "Київський університет", 2008. -309 с.

3. Бурлака С.М. Особливості визначення фінансових результатів діяльності підприємств / С.М. Бурлака // Управління розвитком. - 2013. - № 15. - С. 9194.: [Електронний ресурс]. - Режим доступу: http://nbuv.gov.ua/UJRN/ Uproz_2013_15_43.

4. Самохін Л.В. Проблеми класифікації фінансових результатів та шляхи їх вирішення / Л.В. Самохін // Наукові праці ДонНТУ - 2005. - № 91. - С. 57: [Електронний ресурс].

Стаття відправлена: 03.04.2017 p.

(C) Невгад Ю.О.

\author{
ЦИТ: ua117-087 \\ DOI: 10.21893/2415-7538.2016-05-1-087 \\ УДК 657
}

УДОСКОНАЛЕННЯ ОБЛІКУ ДОХОДІВ В УМОВАХ МСФЗ

Чечуй А. В.

Київський національний університет імені Тараса Шевченка, м. Київ, вул. Васильківська 90а, 03022

\section{IMPROVING ACCOUNTING INCOME UNDER IFRS}

Chechuy A.V.

Taras Shevchenko National University of Kyiv, Kyiv, Vasylkivska 90A, 03028

Анотація. В умовах сучасної ринкової економіки питання щодо обліку доходів $\epsilon$ досить актуальним $i$ вимагає детального дослідження. Підприємства, здійснюючи господарську діяльність, в основному керуються національними стандартами, що зумовлено різними факторами, одними з яких 